\title{
Integrated Marketing Communication as An Element of Visitors' Selection of Heritage Destination: A Theoretical Framework
}

\author{
"Dr. Juthika Konwar, ${ }^{*}$ Dr. Nilanjana Chakrabarty \\ *,\#Assistant Professor, Dept of Business Administration, Assam University, Silchar, Assam, India. \\ "juthikakonwar@gmail.com, "nilanjanachakrabarty.aus@gmail.com
}

\begin{abstract}
Integrated marketing communications (IMC) is a major communication archetype rooted from communication theory. Integrated Marketing Communications (IMC) is known as one of 4ps marketing mix elements. Heritage tourism is based on significant histories, or humanity to attract visitors to discover, to explore, and to enjoy attractions. The purpose of this paper is to identify the components of Integrated Marketing Communication (IMC) as an element for selection of heritage destinations by the visitors. This paper adopts a qualitative approach in identifying the components of IMC which are essential in selection of heritage destination. The identification is primarily based on extensive review of literature based on IMC, Heritage Tourism, and Destination Marketing.
\end{abstract}

Keywords: Advertising, Heritage Tourism, Integrated Marketing Communication, Marketing Communication, Public Relation, Tourism marketing.

\section{INTRODUCTION}

Heritage tourism has become one of the most popular forms of tourism. Many countries across the world have acknowledged it as an instrument of economic development and advocacy of local culture and heritage. Heritage scholars often describe heritage as "contemporary use of the past" (Ashworth 2003). This definition encompasses both tangible and intangible elements of the cultural/heritage environment. Heritage tourism, in fact, occupies a forefront position in the global tourism industry because it involves millions of visitors every year who travel to visit a variety of heritage attractions and sites (Timothy and Boyd 2006). The important role of tourism industry in transforming economic-social-cultural agenda of a region has prompted nations to search for new unique selling propositions (USP) for marketing tourism with an integrated approach. Heritage tourism provides the answer to the host of agencies striving to serve something unique to satisfy the requirements of tourists. It is a well-established fact that Historical/ Archaeological sites, past relics in the form of forts/monuments, museums, customs, traditions, dance, music and values are all serious reflection of heritage of the land, which in turn, has become important components of the tourism product. Heritage tourism categories itself in the special class of tourism based on the search for new, deep and fulfilling cultural experiences, which may be aesthetic, intellectual or psychological. Heritage tourism is recognized as an important force for preserving, maintaining and conserving the aboriginality of the place. Most heritage administrators focus their efforts on research, preservation, and education. With the intensified competition, however, marketing an attraction as a unique " "product', and successfully communicating to prospective visitors becomes vital. The ultimate goal of marketing is to build a unique image, to increase the spending of visitors, and to extend their stay at the heritage site (Pike, 2004). Robinson (1994) suggested that the aim of marketing heritage attraction is to persuade customers that the attraction is the place to which they prepare to travel. Many heritage sites practice "branding" strategy to carry out this goal. Establishing a strong brand becomes a competitive advantage for the heritage destinations as this enables them to distinguish themselves from others (Hankinson, 2004; Pike, 2004). Integrated Marketing Communication (IMC) as a strategic tool which integrates a promotional mix to deliver maximum communication influences to target audiences (Burnett \& Moriarty, 1998; Sirgy, 1998; Vargas, 2005). In practice, the IMC utilizes cross-functional marketing communication tools, for example, advertisement, direct mail, public relations, and word-ofmouth, to achieve its brand communication goals effectively (Pike, 2004). IMC could potentially create the greatest persuasive effect on consumers' encounters with brand contacts (Madhavaram, Badrinarayanan, \& McDonald, 2005). Although IMC has been successfully carried out by many manufacturing and service businesses, it is still relatively new concept to heritage tourism management. The purpose of this paper is to identify the components of Integrated Marketing Communication (IMC) as an element of selection of heritage destinations by the visitors. 


\section{CONCEPTUAL FRAMEWORK}

Tourism is a social, cultural and economic phenomenon which entails the movement of people to countries or places outside their usual environment for personal or business/professional purposes (Understanding tourism: basic glossary, 2014). Tourism is a leisure activity which involves a discretional use of time and money and recreation is often the main purpose for participation in tourism (Ghosh, 2001). Tourism is evolved from the movement of people to and their stay in various destinations. There are two basic factors in tourism, such as the journey to the destination and the stay. In short, tourism means the business of providing information, transportation, accommodation and other services to travellers (Ghosh, 2001). Tourism industry includes all the socio-economic activities that are directly or indirectly involved in providing services to the tourists (Dabour, 2003). Tourism can be classified into several distinct categories. They would include holiday travel, visiting friends and relatives (VFR), business travel, health treatment, shopping, conference, incentive travel, official mission, education, sport and others travel (Malaysia Tourism Promotion Board, 2004). Tourism marketing is an integrated effort to satisfy tourists by making available to them the best possible services. It is a method to transform the potential tourists into actual tourists. It is the safest way to generate demand and expand market (Shamsuddoha, 2005). As an important element of Marketing Mix, promotion plays the vital role in tourism marketing as like any products and services.

\section{- Heritage Tourism}

Heritage is the things of value which are inherited. If the value is personal, it is family or personal heritage; if the value is communal or national, it is of our heritage (Edgell, 2006). Heritage places are those which help an understanding of the past; enrich the present and which will be of value to the future generations. For the places of archaeological and architectural values, it is the people and activities that form the cultural heritage (Ahmed, 2006).

\section{- Heritage Tourists}

The heritage tourist asks for travel experiences that broaden and deepen his or her understanding of other places and people. The heritage tourist wants to experience destinations with a distinctive sense of place.

\section{- Integrated Marketing Communication (IMC)}

Shimp (2010) defined integrated marketing communication as the planning, creation, integration and implementation of all contact points which a consumer has with a certain brand, as potential distribution channels, for messages which may influence directly or indirectly the purchasing process. The IMC message typology presents a good framework for communication planning purposes.

\section{LITERATURE REVIEW}

The heritage and cultural tourism literature has proliferated in the last decade. Theoretical articles and discussions of major issues such as the role of heritage and culture in postmodern society, heritage/cultural markets and artistic manifestations, planning, interpretation, community involvement and/or authenticity are all well represented within the existing literature. Surprisingly, with the exception of some pioneering work by Prohaska (1995) and Silberberg (1995), there is still little quantitative information on heritage and cultural tourists. Heritage tourism gained attention from the late 1980s and early 1990s and is considered to be a broad field of speciality travel in tourism (Zeppel \& Hall, 1991). It is a multifaceted term manifested with a wide range of meanings and, therefore, there are polarized views of it in published literature. Scholarly debate with regard to the nature of heritage tourism still persists, suggesting that heritage is an amorphous concept and a complex phenomenon.

\section{A. Heritage Resources}

Based on their characteristics, heritage can be classified into nature, landscape, monuments, artifacts, activities, people, and sites (Ashworth, Howard, \& Ashworth, 1999). Nature includes plants, animals, and ecosystems, geological and geomorphologic features. Landscape pertains to areas conserved for their aesthetic appeal and their cultural evidence. Monuments include memorial structures and works of architecture representing a specific era or building style. Artifacts are man-made objects that have been collected. Activities constitute our ways of life, such as languages, religious activities, and culture. People are represented as artists, presidents and royal families, etc. Sites represent mythical heritage, which might be connected to certain actual places without physical evidence. These heritage resources symbolize the place, values, and common characteristics of human beings. Archaeological and historic sites, buildings, locations, and facilities having cultural significance in the community should not be neglected (Li, 2003). When these are packaged and developed to attract visitors, they become heritage products (Taiwan Tourism Policy White Paper, 2002). From natural parks to archeological sites, the fascinations of these attractions which relive the past have become important tourism resources. Nevertheless, heritage resources themselves do not automatically become tourism destinations. For a heritage resource to become an attraction to visitors, the site must contain eight characteristics (Silberberg, 1995): perceived quality of the product, awareness, customer service attitude, sustainability, and extent to which a product is perceived to be unique or special, convenience, community support and involvement, and management commitment and capability. 


\section{B. Heritage Tourism}

According to Hall and Zeppel (1990), 'Heritage tourism is a subset of cultural ethnic and educational forms of special interest tourism which includes many aspects of touristic behaviour ranging from examination of the physical remains of the past to the experience of contemporary cultural traditions'. Heritage tourism also includes local cultural traditions, folkloric traditions, artefacts (Hollinshead, 1988) and nostalgia of the past (Smith, 1989). According to Fyall and Garrod (1998), heritage tourism utilizes the sociocultural assets of the area to attract visitors and, thus, enhances its economic activity. Previous research has broadly classified heritage into two categories: tangible and intangible. Tangible heritage is inclusive of all assets that contain a degree of physical embodiment of cultural values (UNESCO 2000). McKercher and Du Cros define intangible heritage as "Traditional culture, Folklore, or popular culture that is performed or practiced with close ties to 'place' and with little complex technological accompaniment" (2002: 83).

Heritage is also referred to as built heritage which can be classified into three categories (Prentice 1993):

- Historic and artistic: Examples include relics with physical/tangible characteristics.

- Scientific: This category refers to elements drawn from birds, animals, rocks etc.

- Cultural heritage: It includes folk, fine arts, traditions, and languages.

In the context of tourism, the word 'heritage' has both cultural and natural connotations (Herbert 1989; Timothy and Boyd 2003; Zeppal and Hall 1992). For instance, Timothy and Boyd (2003) create a heritage spectrum that traverses multiple settings ranging from "natural and pristine to the built-urban and artificial". Richards (1996) defined heritage as a gamut inclusive of ancient monuments, the built urban settings, multiple features of the natural environment, and numerous facets of living culture and the arts. Howard (2003) describes heritage as "anything that someone wishes to conserve or collect and pass on to future generations".

\section{Heritage Tourism and Marketing}

Marketing is a societal process by which individuals and groups obtain what they need and want through creating, offering, and exchanging products and value with others. (Kotler, 2006). Review of marketing definitions in the tourism literature, reveals that tourism is heavily slanted toward customer needs, satisfaction, and relationship building, although traces of society and stakeholder emphases are beginning to emerge. The role of marketing is to integrate different publics of a business or organization. Heritage is a mixture of both past and present generations and can be interpreted as a space that narrates certain events to create an identity (Ateljevic \& Doorne, 2003). When the heritage is linked to tourism, local history and architecture of destination play the central role as an attraction for the visitor and representation of the community. This connection is extended to a higher level due to the tourist's activity (Quan \& Wang, 2004). It has led to the creation of the market which is important pertaining to its historical legacy and is entitled to be preserved ( $\mathrm{Du}$ Cros, 2001). According to Janes (2006), marketing has become a core function in tourism organizations. Webster (1995) asserts that an integrated marketing communication can facilitate greater effectiveness of promotional strategies.

Most of the recent research on heritage tourism marketing is focused on the themes of market segmentation, consumer behaviour, communication and promotion (specifically advertising), and partnerships. Although, there has been a good number of works in heritage tourism literature that seeks to identify different market segments so that customised offerings can be designed for profitable target markets. The distinct basis for market segmentation in tourism sector has been identified to be demographics (Chen and Hsu 2000; Misiura 2006), perceptions (Chhabra, Healy 2003; Waitt 2000), motivation (Kerstetter, Confer and Graefe 2001), activities (Sung 2004), attitude (Poria, Butler and Airey 2003), benefits (Frochot 2005), and spending propensity (Chhabra 2002; Caserta and Russo 2002). These authors concluded that market segmentation research in heritage tourism is decisive in implementing promotional strategies (Cooper and Inoue 1996). Chhabra (2009), emphasised on staying competitive, satisfying consumer needs for increasing marketing effectiveness.

D. Heritage Tourism and Integrated Marketing Communication

Integrated marketing communication represents the planning, creation, integration and implementation of all contact points which a consumer has with a certain brand, as potential distribution channels, for messages which may influence directly or indirectly the purchasing process (Shimp, 2010).

Earlier literature classified marketing communication channels into two categories: interpersonal (occurring on a personal level) and impersonal (mass and promotion based) (Schiffman and Kanuk 1991). The heritage tourism literature used combination of the above two channels. Most of the studies have documented the dependance on interpersonal communication channels (Stynes and Mahoney 1986; Chhabra 2002). External communications or promotions have mainly focused on informative messages for prospects and relevance-, memory-, or connection-based messages for repeat markets (Reid and Reid 1993; Walters, Sparks and Herington et al. 2007).

In order to communicate a marketing message, Integrated Marketing Communication (IMC) offers different tools. According to Aronsson and Tengling (1995), tools used most frequently in tourism industry are: advertising, direct marketing, personal selling, public relation, sales promotion and trade shows. In addition, Smith Perry and Purford (1998) proposed several other tools such as the internet, 
sponsorships, packaging, point-of-purchase, word-of-mouth and corporate identity. Furthermore, print ads are extensively used to promote heritage tourism (Smith and McKay 2001; Manfredo, Bright and Haas 1992). The primary focus is on advertising and the measurement of its effectiveness among selected target markets in heritage tourism literature (Xiao and Mair 2006). Advertising related research in heritage tourism has cantered on brochures, newspapers, radio, television etc., to examine word meanings and imagery perspectives to gauge the impact of messages (MacInnis and Price 1987; Gartner 1993). It is evident from the literature that regardless of the communication strategy used; the core focus of heritage tourism marketing has been on designing promotional strategies and message content appropriate for selected or suggested target markets. The review of the major empirical studies concerning use of Integrated Marketing Communication concepts and tools in tourism sector is presented in Table 1.

Table 1: IMC implementation in Tourism Sector

\begin{tabular}{|c|c|c|}
\hline Authors & Objectives & Methodology \\
\hline $\begin{array}{l}\text { Kulluvaara and } \\
\text { Tornberg (2003) }\end{array}$ & $\begin{array}{l}\text { Describe the IMC strategy } \\
\text { and communication tools } \\
\text { used by Icehotel. }\end{array}$ & Case study \\
\hline Skinner (2005) & $\begin{array}{l}\text { Discuss whether } \\
\text { destination branding } \\
\text { should be applied. Focus } \\
\text { on the ways in which } \\
\text { Wales is promoted as a } \\
\text { tourism destination. } \\
\text { Identify problems } \\
\text { associated } \\
\text { implementing IMC for } \\
\text { place brands. Question the } \\
\text { strategy of total } \\
\text { integration. }\end{array}$ & Content analysis \\
\hline $\begin{array}{l}\text { Elliott and Boshoff } \\
(2008)\end{array}$ & 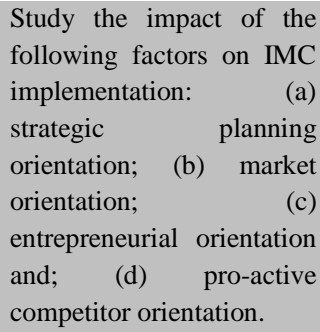 & $\begin{array}{l}\text { Exploratory factor } \\
\text { analysis Multiple } \\
\text { regression analysis }\end{array}$ \\
\hline $\begin{array}{l}\text { Wang, Wu and } \\
\text { Yuan (2009) }\end{array}$ & $\begin{array}{l}\text { To explore the role of } \\
\text { integrated marketing } \\
\text { communications (IMC) on } \\
\text { visitors' selection of a } \\
\text { heritage destination. }\end{array}$ & $\begin{array}{l}\text { Exploratory Study, } \\
\text { Descriptive } \\
\text { Statistics using } \\
\text { Varimax Rotation }\end{array}$ \\
\hline
\end{tabular}

Source: Authors

\section{IMC COMPONENTS IDENTIFICATION}

In promoting a destination, communication channels that are being used include public relations, media campaigns, tourism fairs, online and offline advertising, broadcast and print media, recommendations from family and friends, promotions by travel agents and tour operators, and Carnivals, Festivals, Events and Travel exhibitions. A brief description of each of these components of IMC used in promoting a tourist destination is presented below:

\section{A. Advertising Campaigns in Tourism Industry}

Advertising represents the actual destinations and significantly affects the perception of a place in the minds of the tourists. The role of advertising is not limited to description of tangibles. Tourism destination marketing campaign is a deliberate attempt to constitute attitude towards a destination. Campaigns portray destinations through specific marketing channels and present an image for positive tourist behaviour (Gartner \& Shen, 1992). Destination marketers therefore ensure a firm balance between the image portrayed and organic image of the destination. Piggott, Morgan and Pritchard (2004, p. 207) state that 'limited attention has focused on how the marketing of destinations can reflect socio-political, economic and cultural change'. According to Amitabh Kant (2009, p. 7), Incredible India campaign 'pervade all forms of communication and stimulate the travel consumer's behaviour and decision-making process to competitively position India in the global market place'. This campaign was responsible for increased tourist arrival and an eyeopener for the country to understand the existing potential (Kant, 2009). The resulting figures were amazing, that can be seen as India was positioned 29th out of 45 in Future Brand's Country Index. In 2006, India found its position in top 10 country brands (Kant, 2009). Thereafter, scoring high on 'heritage and culture' and 'history' dimension positioned India 16th in the world for tourism. This shows the power of advertising campaign, that is, if targeted, the right audience with right content can result in raising a destination on top as tourist destination.

B. Public Relations in tourism Industry

Public relations represent a unique way of promoting the organization, its products or services, by building a higher visibility in the public space. Public relations represent a strategic form of communication, which focuses on gaining the audience's understanding and acceptance, as well as on the process of building a good relation between an organization and the public. In the tourist sector, public relations are more than a necessity. The literature argues that the public relations represent the fifth "P" of a marketing strategy: product, price, position and promotion (Wilcox et al., 2009, p.16). According to specialists, cultivating public relations takes longer, but when they are actuated, they can contribute to promoting the company on the market (Kotler, Rackham, 2006, pp.68-78). Public relations may support the tourism public sector, building a positive image and a favourable attitude towards the tourism product, respectively the tourism destination envisaged (Stancioiu, 2000, p.50). The explanation lies in the fact that in the tourism sector, a favourable image creates motivation in making the decision to buy the tourism product. Public relations in tourism are a key element of the marketing mix, 
which resorts to "general influence tools" such as the relations with the media materialized in press tours, conferences on tourism, fairs and expositions, promotional activities, special events (Kotler, Rein, Haider, 2001, p.177).

C. Online promotion in tourism industry

The new entry of many tourist destinations into the market has created the challenge for many countries and forced them to go for promoting tourist places. In recent years, internet has become the most used channel in tourism promotion as well as destination marketing. Therefore, in order to effective use this new form of communication, new strategies have been created. Consequently, it is necessary to highlight the advantages of the web, resources, as well as the best strategies which might help tourism managers to be aware and promote a destination. Tourism promotion can be more effective through word-of-mouth marketing. Word of mouth (WOM) communication is a big part of online connections within the online tourist communities. Particularly, tourism specialists are interested in WOM communication because of its popularity, growth and influence on that communities (Madasu 2013).

In addition, web 2.0 and user generated contents are the most renowned marketing methods of tourism business. Web 2.0 has played a role to express an experience and feedback of a product by sharing photo, blogs, travel review and video sharing. Marketers can observe this sharing and contract with the interested people who have a positive experience at related products. The new technology growth increases the efficiency of the companies to communicate with the customers and their operation process such as booking, distribution and tour management. The appearance of the information technology also increases the power of the consumers. In the past decade, most of the tourism products such as destination choice, flight tickets, accommodation, and car rental service were handled by the travel agencies. The wide range of usages of the internet and search engines make it easier to the customers to select a travel option from a wider selection rather than limited offered by the travel agency or tour operator. (Middleton et al. 2009, 250-269)

Internet marketing is bigger than marketing through brochure as in a brochure the number of page is limited therefore, the amount of information are also limited than a web page. Online usage enable customers to access more photos and videos of destinations and services, which helps to make a right decision on a trip. Moreover, consumers can also compare price on the internet because there are a plenty of options are available on internet (Middleton et al. 2009, 260).

\section{Promotion through social media}

Social media is an online application tool, which allows the user to make co-operation and collaboration on the internet. People with a common interest can gather to share their thoughts, comments and opinions. Social media sites enable companies and firms to advertise and promote their products with better possibilities. The advertiser can create their own website with interesting content and do not have to pay huge sum of money for publishing and distributing. On the other hand, consumers now just not receive the information, but also can interact with other consumers to express their ideas and experiences.

Today's travel companies are more active in social media specially the international ones. Social networks are one of the fastest and most effective ways of communication to spread information to a large group. Social media allows companies to get closer as well as to receive both positive and negative feedback. This feedback helps companies to know about how a product or service is considered in the marketplace (Agresta \& Bough 2010, 3-8).

Social media has an enormous impact on travel and tourism business. Tourism business mostly depends on word-ofmouth communication to share opinions and recommendations. Through Facebook and Twitter customers can share trips and suggestions which are most valuable for tourism promotion. A survey founded that more than half (52 per cent) of travellers plans were affected after seeing friend's pictures of trips. Using social media helps to provide latest promotional offers for instance, short time promotion can be announce on social media when it is not possible in printing media due to limited time (Bennett 2012).

Social media is a "two- way street media" where people communicate and hold conversations with each other online. Instead of traditional one-way communication used in media channel, social media is the mean of two-way communication. According to Sterne (2010), there are six different social media tools such as forums and message boards, revive sites (Yelp), social networks (Facebook), Blogs, micro-blogs (Twitter), bookmarking (Digg, Reddit) and media sharing (YouTube). Almost all of these sites enable the user to interact with each other. Some of them using to ask questions or express opinion, where others using to answer them. While some of these are to give feedback on product for instance, commenting on Amazon.com (Web Trends 2015, Sterne 2010).

\section{E. Role of Tour Operators \& Travel agency}

A significant information source as well as a marketing channel influencing destination image and choice, particularly for international destinations, is travel intermediaries such as tour operators and travel agents (Baloglu \& Mangaloglu, 2001). Tour operators and travel agents, can be considered as a formal as well as social (personal) information source due to their promotional and consultative efforts (Frias, Rodriguez, \& Castaneda, 2008). Particularly for international destinations, the role of travel intermediaries in promoting and creating images of the 
destinations is more important because international travellers are more inclined to use travel intermediaries in their destination selection process (Baloglu \& Mangaloglu, 2001). Travel brochures are another important tool that is being widely utilized by the travel and tour operators to promote tourism destinations. These pamphlets packed with destination information can be the determining factor behind the a visitor's selection of a travel agent or a tour operator (Wicks \& Schuett, 1991)

\section{F. Family and Friends Recommendations}

The word of mouth advertising is the most credible source among the tourist in terms of selecting a destination. No matter from whatever source they got the information about a destination, an average traveller would like to verify its authenticity from his/her friends and relatives. According to Nielsen's latest Global Trust in Advertising report, which surveyed more than 28,000 Internet respondents in 56 countries, 92 percent of consumers around the world say they trust earned media, such as recommendations from friends and family, above all other forms of advertising (Consumer Trust in Online, Social and Mobile Advertising Grows, 2012). Thus word of mouth advertising through friends and family has become the "social proof" that travellers rely on. The influence of family and friends recommendations on visitor's selection of destination has increased since the proliferation of social media platforms. Social media platforms like Facebook, Instagram, Whatsapp etc. have become a platform to share pictures of your vacation, short trips or any place you visit along with remarks about the place; which is likely to influence the travel plans of many in your social network. This is due to the fact that consumer-created information is likely to be more credible than seller-created information, because credibility of information is often positively related to the trustworthiness of the information source (Wilson \& Sherrell, 1993).

\section{G. Role of Broadcast and Print Media}

The travel journalists, media experts on travel, newspaper articles and blogs and Broadcast media i.e. Television and Radio programs creates awareness about the places of tourist interest, tourism, tourist season (peak and lean), image, scope of shopping, resources, hospitalities, peoples, culture and heritage to cater to the needs of prospective and actual tourists. Now a days we have travel channels in Television that are dedicated to promotion of tourism both domestic and international. In case of Print media, News Papers create a carryover effect on decision making process of tourists. According to the study of Kim, Lee, Mjelde, and Lee (2014) about the carryover effect, for example, newspaper reports had a positive effect on attendance with (Kim, Mjelde, \& Lee, 2014) this media effect increasing for the first four days after publication. Almost all the leading newspapers regularly feature tourism news and articles in their daily or special edition publications. For example,
Every year before a long vacation like Pooja vacation in West Bengal, Summer Vacation in northern India and southern India number of magazines like (Outlook Traveller) regularly feature different excellent and magnificent articles to attract one segment of tourist community to participate in long trip and short trip either in India or in abroad (Kumar, 2014). Again, the Film -induced tourism or movie-induced tourism is a segment of Television tourism that is gaining more scholars attention in recent years. People get attracted to the destinations featured through films and television series which are not directly related to tourism promotion campaigns.

\section{H. Carnivals, Festivals, Events and Travel exhibitions}

The role of carnivals, festivals, events and travel exhibitions in promoting a tourist destination is indubitable. Through these carnivals, festivals, events and exhibitions cultural significance is expressed through the preservation and promotion of tradition and cultural heritage, social significance in promoting the socialization of the local community, as well as attracting foreign and domestic guests (Simin \& Živkucin, 2018)

One of the most culturally unifying and creative extravaganza is celebrated as carnivals in various tourist destinations. The key feature of carnival is the equalization of all people and the enjoyment of a joyful atmosphere (Simin \& Živkucin, 2018). The most famous and most visited world carnivals like Rio de Janeiro and Venice attracts thousands of tourists per day from all over the world.

Festivals are another attraction of any destination that attracts tourists. Tourists are attracted by many elements of a festival, the most important of which seems to be interesting, sometimes exotic culture, presented during the events (Quinn, 2010). As regards the natural heritage, festivals may promote ideas related to its preservation (environmental protection, protected natural areas), as well as those of sustainable development and tourism (Cudny, 2013). In recent years, there has been a considerable increase in the use of local festivals as an instrument for promoting a destination. The most obvious reasons for the popularity of the local festival as a tourism promotion tool are that (1) festivals increase the demand for local tourism, and (2) successful festivals can help recreate the image of a place or contribute toward the exposure of a location trying to get on the tourism map (Felsenstein \& Fleischer, 2003)

From the perspective of the tourism industry, events are highly appreciated as attractions, catalysts, animators, marketers of places, and creators of the image of the destination (Simin \& Živkucin, 2018). Getz (2008) specifically highlights the importance of "hallmark" events (big events) to create the image of destination, destination marketing and branding of destinations, and suggests that 
these events often give the destination a competitive advantage.

Exhibitions are another attraction that draws tourists to any location. The fundamental premise of any exhibition is to bring together the purveyor of a message with its recipients, thereby making face-to-face contact between the exhibitors and their target audience and creating positive emotions for participants (Whitfield \& Webber, 2011). The meeting, convention or exhibition serves as the primary purpose for travel and the focus is a multi-faceted event of a fixed time duration that involves speakers, seminars, workshops, exhibitions, banquets, association meetings and social events (Rogerson, 2005).

\section{FINDINGS}

A review of literature in the previous section reveals that there are various components of integrated marketing communication that impact the visitor's selection a heritage destination. All these components can be categorized in four main IMC categories i.e. Advertising, Direct Sales and Promotion, Interactive/ Internet Marketing and Public Relations for tourism sector as follows:

Table 2: IMC Components categorization

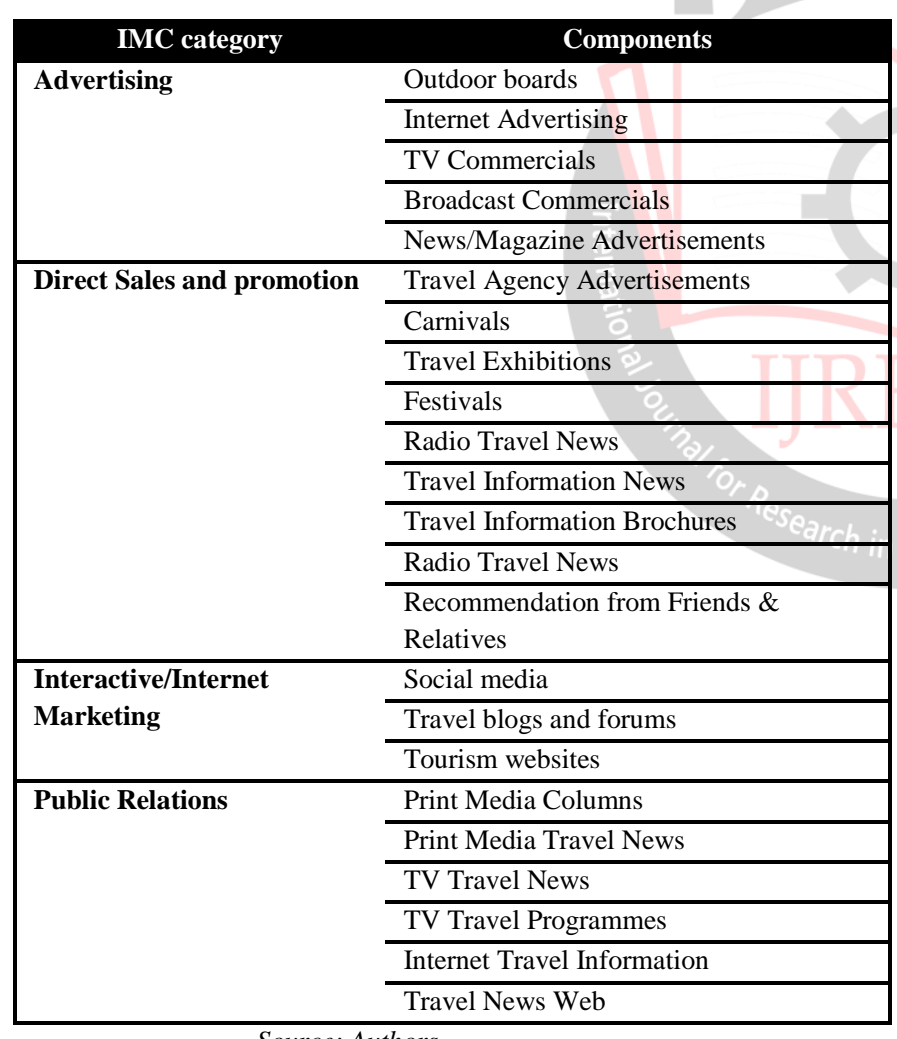

Source: Authors

\section{CONCLUSION}

Economically the tourism sector plays a very significant role in any country or region's economy. Further, tourism creates a platform for social, political and educational exchanges among people from different parts of the world, which is the most important non-economic benefit of it. Recognizing these benefits of tourism marketers are competing to pull more and more tourists to their destinations. To gain a competitive advantage and to utilize the marketing tools optimally, it is becoming essentially important for the marketers to understand how the various components of tourism marketing are perceived by the consumers i.e. the tourists. Marketing tools and channels have evolved and taken various forms in $21^{\text {st }}$ century making it difficult for the tourism marketers to choose the right combination of tools that will hit the bull's eye. Therefore, it is very important for the tourism marketers to integrate the available marketing communication components and break through the barriers of noise to reach their target market. In this process the first step is to identify the components of IMC in tourism, thus a theoretical overview is presented in this paper along with a categorization of components of IMC for tourism marketers. These components and categorization is to stand the test of empirical research for further implementation in practical field. The findings are expected to help heritage administrators understand heritage visitors and formulate marketing strategies and quality management plans to cater effectively to target segments.

\section{ACKNOWLEDGEMENT}

This paper is an outcome of the Research Project sponsored by Indian Council of Social Science Research (ICSSR) New Delhi [Grant no02/72/2017-18/RP/Major]. We feel privileged to acknowledge ICSSR for providing the financial assistance for the research work.

\section{REFERENCES}

[1] Agarwal, S., Bhatt, A., Kapoor, N., Moutinho, T., Van Herwarde, G., \& Walker, K. (2013). Promoting Ecotourism in Himachal Pradesh: A Report of the IIT, Mandi, 2013.

[2] Agresta, S. \& Bough, B.B. 2010. Perspective on Social Media Marketing. Boston: Cengaga Learning.

[3] Ahmed, I. "A Participatory Approach to Conservation: Working With The community to save the cultural Heritage of Panamnagar". BRAC University Journal, Vol 3, 25-33.

[4] Ashworth, G. J. (2000). Heritage, tourism and places: a review. Tourism Recreation Research, 25(1), 19-29.

[5] Baloglu, S., \& Mangaloglu, M. (2001). Tourism destination images of Turkey, egypt, Greece, and Italy as perceived by US-based tour operators and travel agents. Tourism Management 22(1), 1-9.

[6] Bennett, S. 2012. The Impact of Social Media On travel And Tourism. Social Times. Available: http://www.adweek.com/socialtimes/socialmedia-travel-hospitality/466163.

[7] Consumer Trust in Online, Social and Mobile Advertising Grows. (2012, November 11). Retrieved 06 02, 2019, from www.nielsen.com: https://www.nielsen.com/us/en/insights/article/2012/consumer-trust-inonline-social-and-mobile-advertising-grows/

[8] Cudny, W. (2013). Festival Tourism- The Concept, Key Functions and Dysfunctions in the Context of Tourism Geography Studies Geographical Joural 65(2), 105-118.

[9] Dhar, P.N. (2008).Cultural and Heritage Tourism, Kanishka Publisher, New Delhi. El-Ansary, A. Frost, R. \& Strauss, J. 2006. E-Marketing (4th ed). London: Pearson Education. 
[10] Felsenstein, D., \& Fleischer, A. (2003). Local Festivals and Tourism Promotion: The Role of Public Assistance and Visitor Expenditure. Journal of Travel Research 41(4), 385-392.

[11] Elliott, R. and Boshoff , C . (2008). The influence of business orientations in small tourism businesses on the success of integrated marketing communication . Management Dynamics 17 (4), $32-46$

[12] Frias, D. M., Rodriguez, M. A., \& Castaneda, A. (2008). Internet vs.travel agencies on pre-visit destination image formation: An information processing view. Tourism Management 29(1), 163-179.

[13] Getz, D. (2008). Event tourism: definition, evolution, and research. Tourism Management 29(3), 403-428.

[14] Ghosh, B (2001). Tourism and Travel Management : Vikas Publishing House Pvt. Ltd., New Delhi.

[15] Hofstede, G. (1997). Cultures and Organizations: Software of the mind. New York: McGraw Hill; 1 edition. ISBN-10: 0070293074 | ISBN13: 978-0070293076. $279 \mathrm{p}$

[16] ITDC. (2003). India's North East: paradise unexplored, Travellers companion.

[17] Kim, k. T., Mjelde, C. K., \& Lee, M. H. (2014). The carryover effect of newspaper reports on a mega event: Ex post analysis of the 2012 Expo Yeosu Korea. Asia Pacific Journal of Tourism Research 19(9), 1009-1022.

[18] Kotler, P., Rackham, N. \& Krishnaswamy, S. (2006). Ending the war between sales \& Marketing. Harvard Business Review, 84 (7), 68-78.

[19] Kotler, P., Rein, I., Haider, D. (2001). Marketingul locurilor. Bucureşti: Editura Teora.

[20] Kulluvaara , C . and Tornberg , J. (2003 ). Integrated marketing communication and tourism . A Case Study of Icehotel. BS thesis, Lule å University of Technology, Sweden

[21] Kumar, S. P. (2014). Role of Media in the Promotion of Tourism Industry in India . Global Review of Research in Tourism, Hospitality and Leisure Management 1(3), 187-192.

[22] Madasu, P. (2013). Social media marketing and promotion of tourism. Vol. IX. Available: http://www.smsvaranasi.com/insight/Social\%20media\%20Marketing\%20a nd\%20Promotion\% 20of\%20tourism.pdf. Accessed 13 march 2015

[23] Middleton, V. T. C. Fyall, A. Morgan, M. \& Ranchhod, A. (2009). Marketing in Travel and Tourism (4th ed.). Oxford, UK: ButterworthHeinemann.

[24] Middleton, V. T.C. \& Clarke, J. (2002). Marketing in travel and tourism (3rd ed.). Butterworth- Heinemann.

[25] Quinn, B. (2010). Arts festivals, urban tourism and cultural policy. Journal of Policy Research in Tourism, Leisure \& Events 2(3), 264-279.

[26] Rogerson, C. M. (2005). Conference and Exhibition Tourism in the Developing World: The South African Experience . Urban Forum 16(2), 176-195.

[27] Silberberg, T. (1995).Cultural tourism and business opportunities for museums and heritage sites. Tourism Management, 16(2), 361-365.

[28] Simin , M. J., \& Živkucin, S. (2018). The Impact of Branded Events on The Success of a Tourist Destination. Knowledge - International Journal 23(1), 281-285.

[29] Skinner, H . (2005). Wish you were here? Some problems associated with integrating marketing communications when promoting place brands . Place Branding 1 (3), $299-315$.

[30] Sterne, J. (2010). Social Media Metrics, How to Measure and Optimize Your Marketing Investment. New York: John Wiley \& Sons, Inc.

[31] Stancioiu, A.F. (2000). Strategii de marketing în turism. Bucureşti: Editura Economică.

[32] Timothy, D. J., \& Boyd, S. W. (2003). Heritage tourism. Harlow, England: Pearson.

[33] Wang, Y. Wu, C. \& Yuan, J. (2009). The Role of Integrated Marketing Communication on Heritage Visitors Destination. Journal of Quality Assurance in Hospitality \& Tourism 10(3), 218-231.

[34] Web Trends. (2015). What is Social Media? Available: http://webtrends.about.com/od/web20/a/social-media.htm.

[35] Whitfield, J., \& Webber, D. J. (2011). Which exhibition attributes create repeat visitation? International Journal of Hospitality Management $30(2), 439-447$.

[36] Wicks, B. E., \& Schuett, M. A. (1991). Examining the role of tourism promotion through the use of brochures . Tourism Management 12(4), 301-312.

[37] Wilcox, D.L., Cameron, G.T., Ault, P.H., Agee, W.K. (2009). Relaţii publice: strategii şi tactici. Bucureşti: Curtea Veche Publishing

[38] Wilson, J. E., \& Sherrell, L. D. (1993). Sources effects in communication and persuasion research: A meta-analysis of effect size. . Journal of Academy of Marketing Science 21(2), 101-112. 